\title{
Notes on the genus Thelidium (Verrucariaceae, lichenized Ascomycota) in the Kujawy region (north-central Poland)
}

\author{
Mirosława Ceynowa-Gieldon, Edyta Adamska
}

\begin{abstract}
Nicolaus Copernicus University, Faculty of Biology and Environment Protection, Chair of Geobotany and Landscape Planning, Lwowska 1, 87-100 Torun, Poland, e-mail:ceynowa@umk.pl, adamska@umk.pl
\end{abstract}

\begin{abstract}
Thelidium incavatum, Th. minutulum, Th papulare, Th. rimosulum and Th. zawackhii have been identified from the Polish lowlands. Many sites of the above species are located in industrial and urban areas of the Kujawy region. The species are illustrated and described based on the examined material. An identification key to the species and thier distribution are provided.
\end{abstract}

Key words: lichenized fungi, calcicolous lichens, taxonomy, chorology.

\section{Introduction}

The genus Thelidium consists of inconspicuous, difficult to study crustose species requiring special attention. Therefore previous data on the ecology and the distributions of its representatives are scanty. An overall wiew of the knowledge of Thelidium and the other lichens in Poland gave Nowak and Tobolewski (1975) in their monograph contained keys to identification Polish lichens. Later, some interestring records of distributions the species of Thelidium were added by Kozik (1977), Alstrup \& Olech (1992), Bielczyk (2003), Kiszka (1997), Kościelniak \& Kiszka (2003), Śliwa \& Krzewicka (2012) and others autors. Fałtynowicz (2003) summarized the state of knowledge of the distribution of lichen, on the basis of data from other autors, and gave a list of the countries from wich species have been recorded in Poland. His annotated checlist contained 22 species of the genus Thelidium so far recorded in Poland but most of this species are calcicolous species encountered only in mountains and uplands.

In the lowland of Kujawy, remote from the mountainous regions, the following species from the genus Thelidium have been identified: Thelidium incavatum, Th. minutulum, Th papulare, Th. rimosulum and Th. zawackhii. The most common representative of the genus Thelidium in the lowland is Thelidium zwackhii, already recorded from Kujawy at about 20 localities (Ceynowa-Giełdon 2001). Thelidium incavatum and Th. papulare are new species to Kujawy and the Polish lowland, Th. rimosulum is recently described from Kujawy (Ceynowa-Giełdon 2007) and known only from this area, and Thelidium minutulum is rare, found both in the lowlad and montains.

Thelidium incavatum, Th. minutulum and Th. papulare are listed as an near threatened (NT) on the Red List of extinct and threatened lichen in Poland (Cieśliński et al. 2006) however Thelidium zwackhii has been included, in some countries, on the regional Red Lists of threatened lichenized fungi (Cieślińsiki \& Łubek 2003; Czarnota 2003).

In respect of morphology, the species from Thelidium are very similar to the other species from family Verrucariaceae. It differs from the other genera of this family mainly in the structure of spores. Thelidium have multicellular spores equipped with 1-3 (-5) transvere septa. However the saxicolous species of Thelidium which occur in Kujawy region highly polluted under the influence of limestone industry are often poorly developed, devoid of healthy spores, and thus difficult to identify. Some degraded spores - shrivelled or glued together and part of these 
degraded spores resemble muriform spores characteristic of the genus Polyblastia, which can lead to misidentification between representatives of the two genera, especially that even in well developed specimens, the differences between some representatives of these genera are indistinct (Swinscow 1971).

The aim of this note is to present the species very rare in the lowland, found in Kujawy mainly in the industrialized areas.

\section{Material and methods}

The material studied is deposited in the herbarium of Nicolaus Copernicus University in Torun (TRN). It was collected by the authors from the industrialized zone of Kujawy region, by the upper course of the Noteć river and some neighbouring areas adjoining the lower Vistula. The $\mathrm{Ku}-$ jawy area is situated mostly in the large ATPOL grid square (Zając 1978) of 100x100 km denoted by letters CC. Locations of species are coded according to this grid square system in 10x10 km squares.

The main research material was collected mostly in the territory of cement and limestone manufacturing plants in the villages of Piechcin and Wapienno, not far from the town of Inowrocław, on dumps and old walls of limestone and dolomite quarries.

Descriptions of species are based on the material examined. Drawings were prepared using the drawing tube. Measurements of ascomata, ascospores and other structures were made on specimens mounted in water. Only well-developed spores were measured and in the majority of cases those outside the asci.

\section{Key for the identification of species (from the genus Thelidium occurring in Kujawy)}

1 Perithecia with an involucrellum 2

$1 *$ Perithecia without an involucrellum 3

2 Mature ascospores 1-septate, $<20 \mu \mathrm{m}$ long

Th. rimosulum Ceyn.-Giełd.

$2 *$ Mature ascospores 3-septate, $>20 \mu \mathrm{m}$ long

Th. papulare (Fr.) Arnold

3 Mature ascospores 1-septate

Th. minutulum Körber

3* Mature ascospores 3-septate

4 Perithecia immersed in pits in limestone; thallus endolithic

Th. incavatum Mudd

4* Perithecia not immersed in pits; thallus superficial

Th. zwackhii (Hepp) A. Massal.

\section{The species}

Thelidium incavatum Mudd

Syn.: Thelidium epipolaeum Arnold, Amphoroblastia calcivora (Nyl.) Servít, Amphoroblastia incavata (Mudd) Servít

Thallus endolithic, forming a dirty cream-coloured stain, continuous or finely cracked. Perithecia about 200 $\mu \mathrm{m}$ diam., surrounded by a narrow gap, almost completely immersed in pits with only the ostiole visible; perithecia often leave empty pits when they fall out. Involucrellum

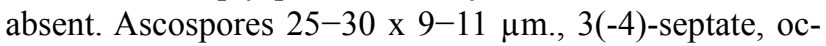
casionally with 1 longitudinal septum (Fig. 1).

Notes. In the collected material, small pits in the rock caused by $T$. incavatum are the most conspicuous under a binocular magnifying glass; they are often empty - after fruiting bodies fell off, or they contain dead thalli and fruiting bodies devoid of well-developed spores. Only after more detail investigation, small clusters of younger, healthy thalli can be found with characteristics of Thelidium incavatum.

Habitat. At the locality found in Wapienno, in Kujawy, Thelidium icavatum grows on a calcareous wall, in the bottom part of the quarry, slightly shaded by trees, in the place that has not been exploited for 20 years. There are the following accompanying lichens: Protoblastenia rupestris (Scop.) J. Steiner, Verrucaria nigrescens Pers. and Thelidium papulare (Fr.) Arnold.

Distribution in Poland. Thelidium incavatum is new to Polish lowland. It was in Poland previously reported only from the southern part of the country (Nowak \& Tobolewski 1975; Faltynowicz 2003). It is known from the Pieniny Mts (Kiszka 1997), West Tatras (Bielczyk 2003; Śliwa \& Krzewicka 2012) and the Sudety Mts (Kossowska 1999).

General Distribution. Thelidium incavatum has a boreal-mediterranean distribution typ (Wirt 1995a). Its distribution in Europa is associated with larger areas of calcareous autcrop. It occurs mainly in upland and montainous areas, particulary in the Alps and Carpathians (Bielczyk et al. 2004) from France through central Europe, but its localities have been known also from Danemark (Søchting \& Alstrup 2002), Norwy and Sweden (Santesson et al. 2004).

Specimens examined. Poland. The Kujawy District: CC-56 - Wapienno near Piechcin 8 July 2004; between Piechcin and Bielawy 11 September 2004 leg. M. Ceynowa-Giełdon (TRN).

\section{Thelidium minutulum Körber}

Syn.: Thelidium acrotellum Arnold

Thallus on soil, brown-grey to geenish when wet, thin to moderately thick, forming small patches. Perithecia very small, globose to depressed-ovate, 100-160 $\mu \mathrm{m}$ diam, prominent or partially immersed in thallus; involucrellum absent; exciple brown to blackish-brown, pale below. As- 

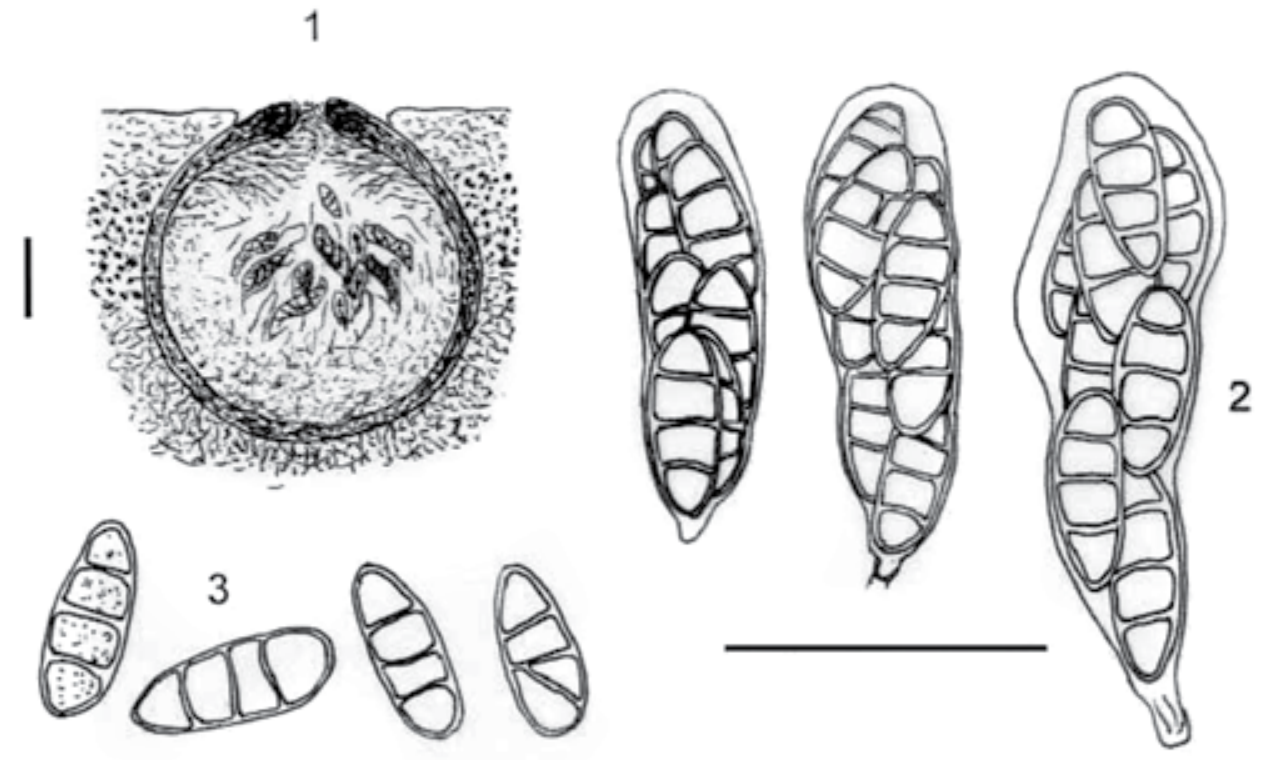

Figure 1. Thelidium incavatum (original; locality: Wapienno 8.07.2004) 1 - section of perithecium; 2 - asci; 3 - ascospores. Scales: $1=50 \mu \mathrm{m} ; 2 \& 3=50 \mu \mathrm{m}$
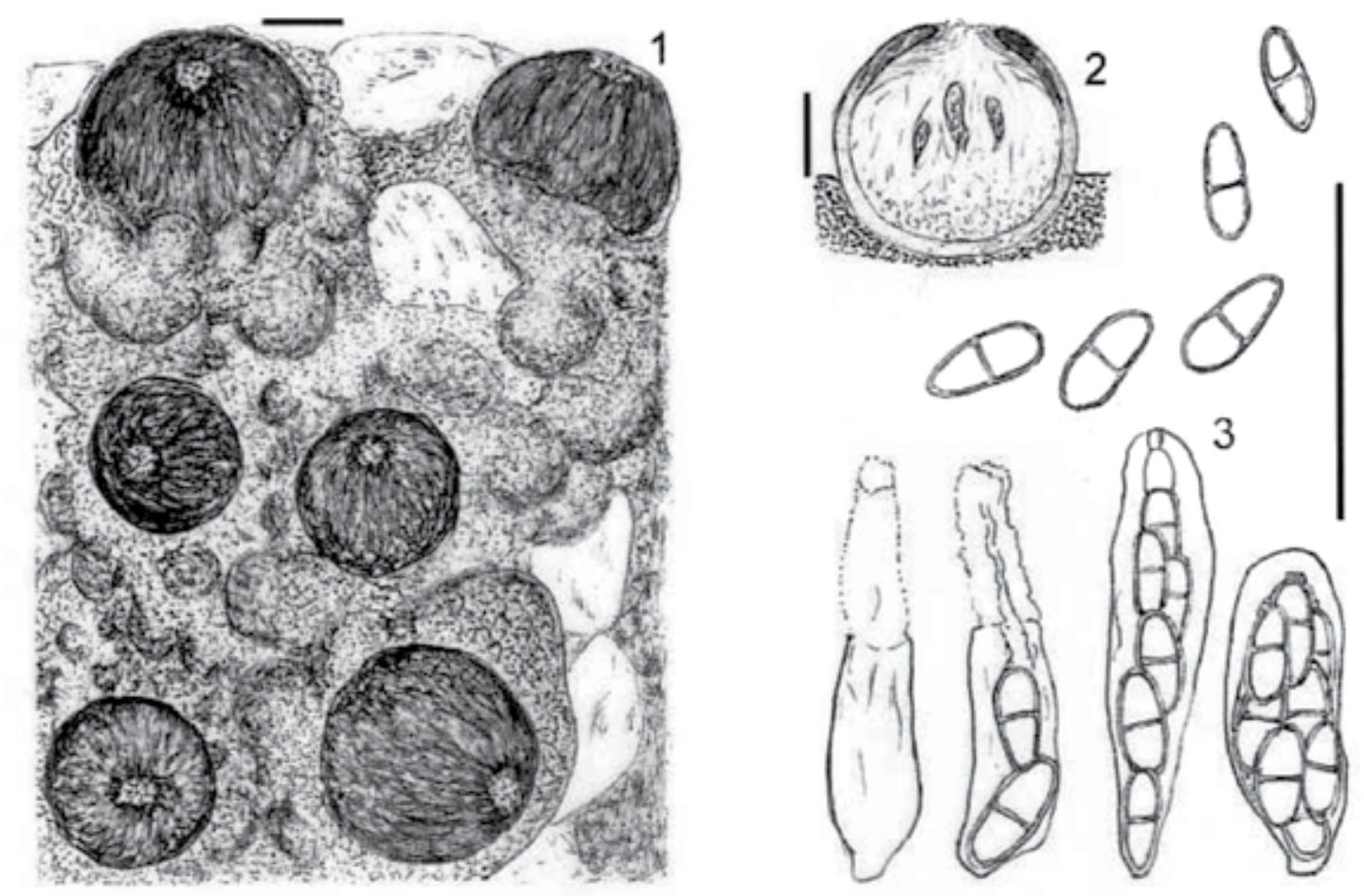

Figure 2. Thelidium minutulum (original; locality: Rzadka Wola 1.06.1995), 1 - thallus with perithecia; 2 - secion of perithecium 3 - asci and ascospores. Scales $=50 \mu \mathrm{m}$ 
cospores colourless, ellipsoid, (13)15-22 x 5-8 $\mu \mathrm{m}, 1$-septate (Fig. 2).

Notes. The specimen collected in Kujawy characterized by the small ascospores and small perithecia in poor condition, mostly with empty asci. Morphologically the species resembles Verrucaria bryoctona (Th. Fr.) A. Orange and $V$. xyloxena Norm., with which it has sometimes been confused. Thelidium minutulum differs, however, due to septate ascospores and the base of the excipulum (Orange 1991).

The status of $T$. minutulum Körber requires further study.

Habitat. Thelidium minutulums grow on calcareous soil as well as on non-calcareous substrates, on rocks and pebbles, rarely on soils, in humid habitats. In Kujawy it was recorded, together with Thelidium zwackhii, on clay soils, in the Zgłowiączka River Valley (Ceynowa-Giełdon 2001), and in Torun on the ruins and on the leather (Adamska 2010, 2012).

Distribution in Poland. Until now, this species is known in Poland only from few sites, recorded both in the mountains and lowlands (Fałtynowicz 2003). In the Polish lowland it was also found in Puszcza Borecka Forest (Zalewska 2012) and Toruń city (Adamska 2010, 2012). In the Polish Carpathians it was reported from West Tatra Mts (Śliwa \& Krzewicka 2012), the Beskidy Mts (Nowak 1965; Bielczyk 2003; Kościelniak \& Kiszka 2003) and from the Rożnów-Cieżkowice foothills (Kozik 1977).

General Distribution. Thelidium minutulum is distributed in European in temperate and submediterranen zones (Wirt 1995a) from Spain (Barreno \& Renobales 1985), France and British Isles (Purvis et al. 1994) througt central Europe (Zschacke 1934). In northen it has been reported from Denmark (Søchting \& Alstrup 2002), Fenoscandia (Santesson et al. 2004) and Lithuania (Motiejūnaitè 2002). In the south it can be encountered in Italy (Zschacke 1934). Outside Europe, its localities have been known in North America (Harris \& Lendemer 2005).

Specimens examined. Poland. The Kujawy District: DC-82 - between Rzadka Wola and Brześć Kujawski by the Zgłowiączka river 1 June 1995, leg. M.Ceynowa-Giełdon (TRN); CD-40 - Toruń, by the Poznańska street 11 September 2004, leg. E. Adamska (TRN); CD-30 - Toruń, on the ruins Dybowski castle 20 June 2006, leg. E. Adamska (TRN).

\section{Thelidium papulare (Fr.) Arnold}

Syn. Verrucaria papularis Fr., Polyblastia papularis (Fr.) Servít

Thallus immersed to superficial, greyish to grey-brown, often cracked. Perithecia about $500 \mu \mathrm{m}$ diam., forming conspicuous projections; involucrellum conspicuous, reaching halfway down the perithecium or almost its base. Ascospores 30-55 x 12-20 $\mu \mathrm{m}, 3(-4)-$ septate, rarely with 1(-2) longitudinal septum (Fig. 3).
Habitat. This species grows in Kujawy on calcareous rock, in sunny places, together with Thelidium incavatum.

Distribution in Poland. Thelidium papulare was recorded in Kujawy about $250 \mathrm{~km}$ to the north of the nearest, known locality of the same species, situated in southern Poland and about $400 \mathrm{~km}$ to the south of its sites recorded in the territory of Fennoscandia (Santesson et al. 2004). In southern Poland the species was defined as frequent in the Kraków-Wieluń Upland (Nowak 1961), in the Pieniny Mts (Tobolewski 1958), the Sudetes (Eitner 1901; Kossowska 1999), and as rare or relativery rare in the Bieszczady Mts (Kościelniak 1998, 2004; Kościelniak \& Kiszka 2003), and in the Polish Tatra Mts (Alstrup \& Olech 1992; Śliwa \& Krzewicka 2012).

General Distribution. This species is widely dispersed in Europe. It probably occurs in any larger area with outcrops of calcareous rocks, although in its many part it is rare or very rare, as in e.g., she Baden-Würtenberg German state (Wirth 1995b). According to Wirth (1995a), Thelidium papulare has been regarded as an arctic-mediterranean-mountain species. Its localities have been known also in North America (Wong \& Brodo 1990) and in Australia (McCarty 2006).

Specimens examined. Poland. the Kujawy District: CC-56 - Wapienno near Piechcin 13 July 1993, Wapienno 8 July 2004, leg. M. Ceynowa-Giełdon (TRN).

\section{Thelidium rimosulum $\mathrm{M}$. Ceynowa-Giełdon}

Thallus epilithic, dark grey or dull olivaceous brown to blackish brown, thin or moderately thick, cracked to areolate; areoles up to $700 \mu \mathrm{m}$ wide, angular or rounded. Sterile thalli often with soredia or isidia; soralia cream coloured, mostly erumpent, irregularly rounded, up to 100$200 \mu \mathrm{m}$ diam. Perithecia up to $460 \mu \mathrm{m}$ diam., prominent to entirely immersed in the thallus. Involucrellum conspicuous, dimidiate or extending to the exciple-base level. Ascospores $(11-) 13-17(-19) \times 5-7(-8) \mu \mathrm{m}$, oblong-ellipsoid to soleiform, 1-septate (Fig. 4).

Notes. The species distinguished from many other species of the genus by its small bicellular ascospores and characteristically sorediate thallus. Some of its thalli degenerated (Ceynowa-Giełdon 2007).

Habitat and distribution. It grows in sunny conditions on small limestone rocks by a limestone quarry, associated with Verrucaria muralis Ach., V. nigrescens Pers., Candelaria aurella (Hoff.) Zahlbr. and other lichen species. Found only in Kujawy between Piechcin and Bielawy.

Specimens examined. Poland. the Kujawy District: CC-56 - Piechcin 23 September 1994 (typ), Piechcin 25 September 2003 (isotyp), between Piechcin and Bielawy 11 September 2004, leg. M. Ceynowa-Giełdon 2006 (TRN). 

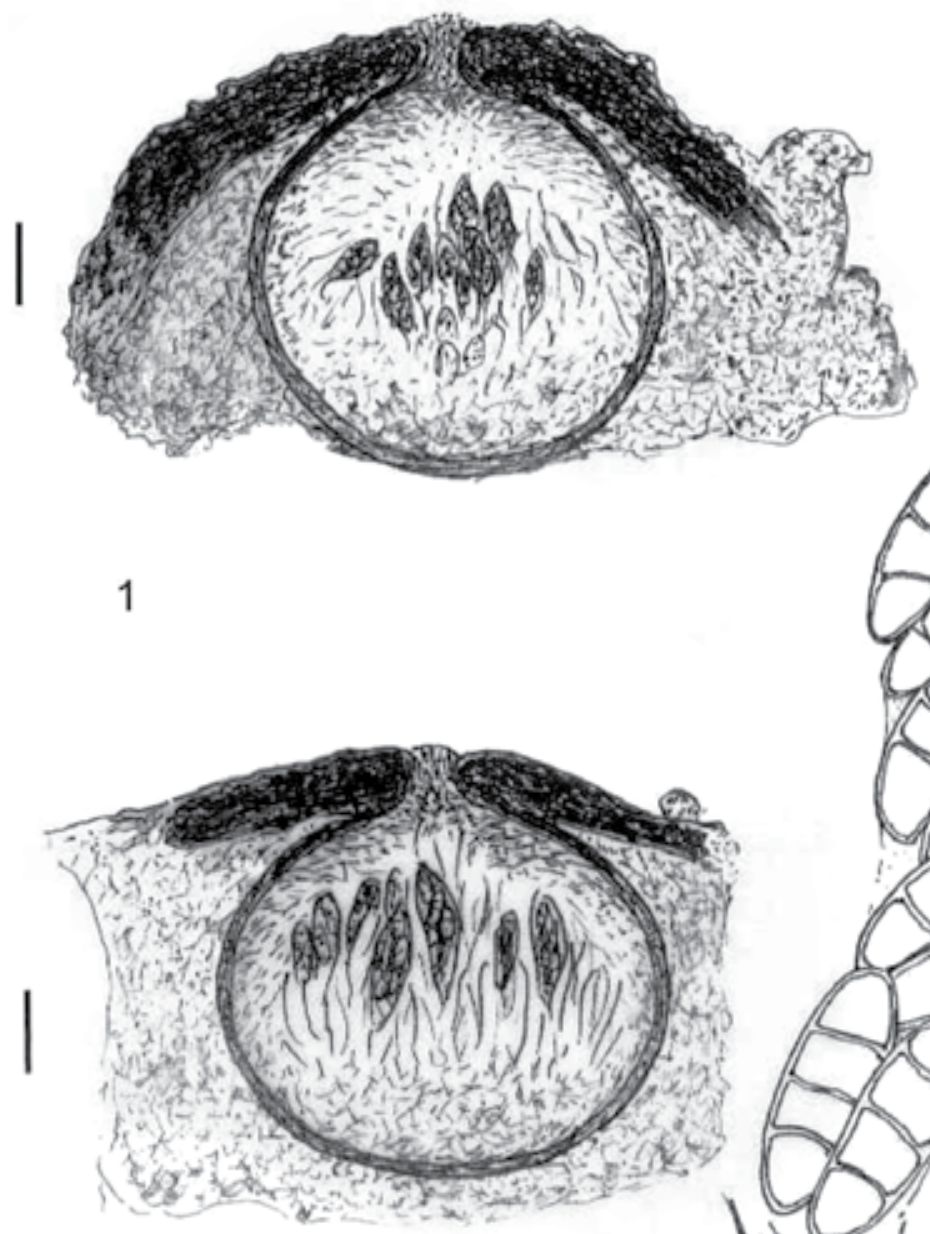

(1)
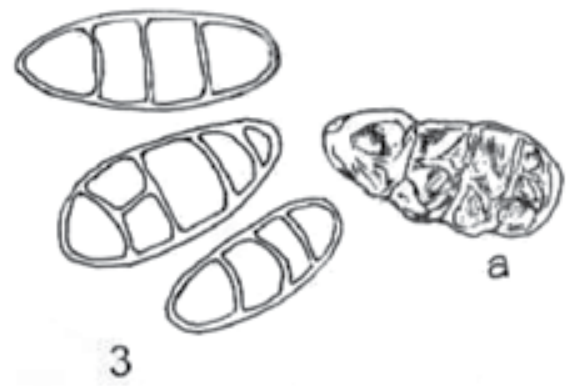

3
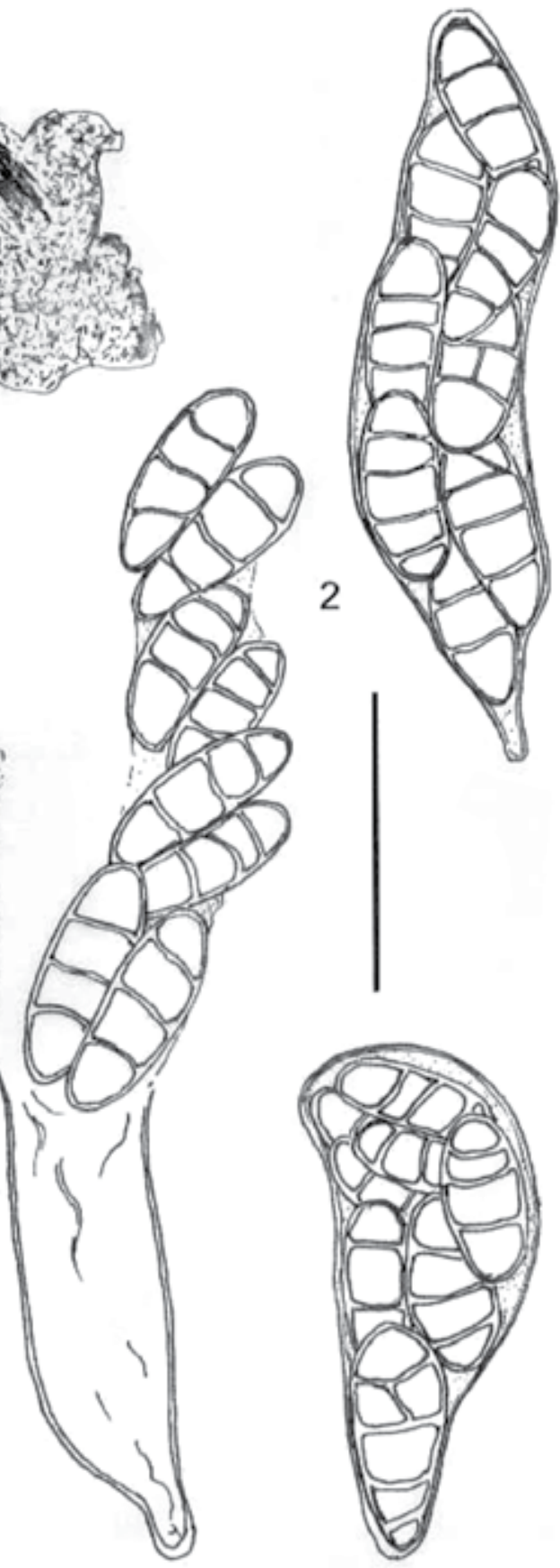

Figure 3. Thelidium papulare (original; locality: Wapienno 13.07.1993), 1 - sections of perithecia; 2 - asci with ascospores; 3 - ascospores; a - degenerete. Scales $=50 \mu \mathrm{m}$ 


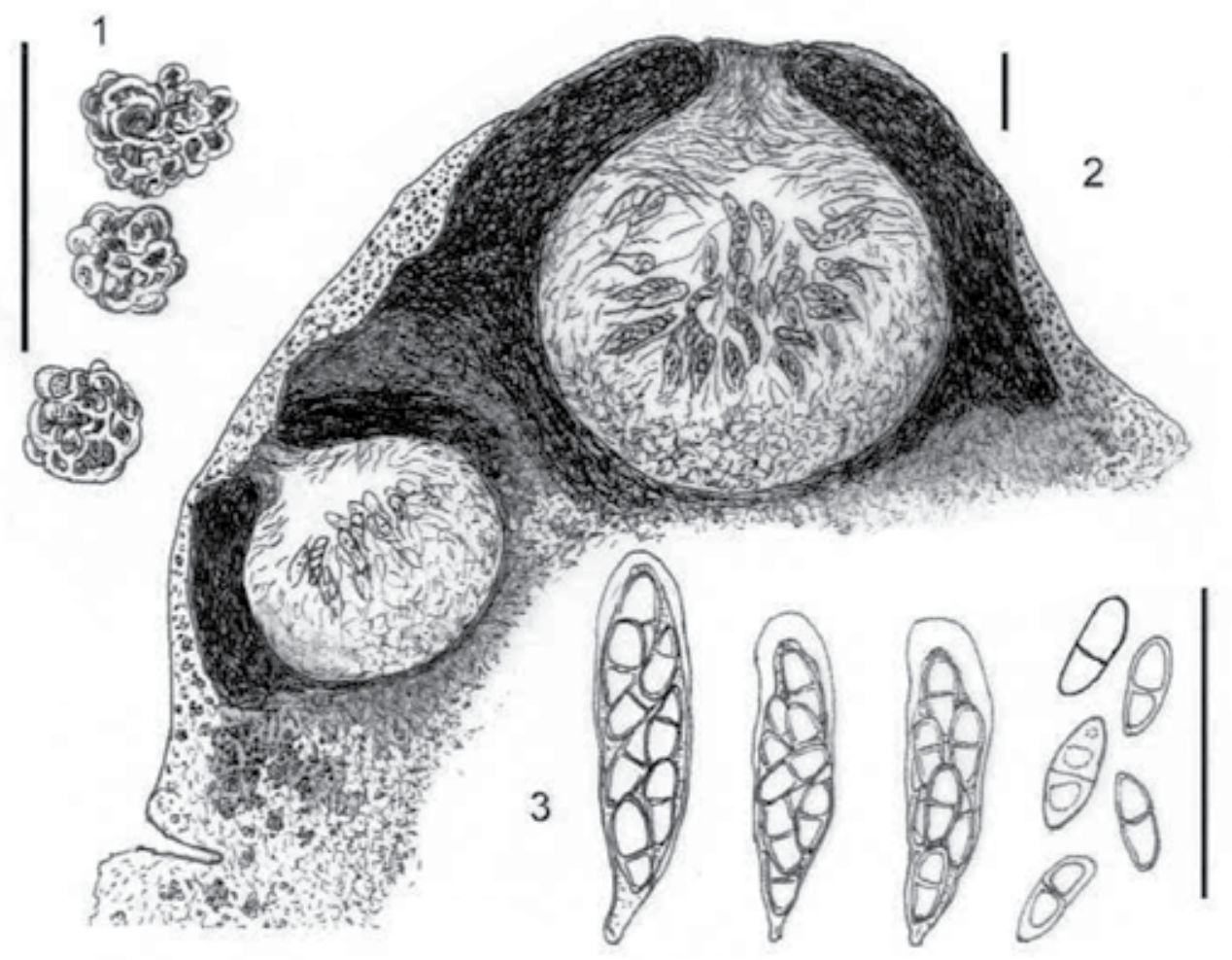

Figure 4. Thelidium rimosulum (original, locality: Piechcin 23.09.1994), 1- soredia, 2- vertical cross-section through thallus with perithecia (diagrammatic); 3 - asci and ascospores. Scales $=50 \mu \mathrm{m}$

Thelidium zwackhii (Hepp) A. Massal

Syn. Thelidium fuistigii Körb., Th. xylospilum (Nyl.) Nyl., Verrucaria geophila Nyl.

Thallus superficial, terricolous, grey-green to brownish grey, very thin, effuse. Perithecia numerous, up to 300 $\mu \mathrm{m}$ diam., spherical to broadly ovoid., prominent to about half-immersed in thallus. Involucrellum absent; exciple blackish-brown, pale below. Ascospores 25-32 x 10-12 $\mu \mathrm{m}$, at first 1- septate, but later becoming 3-septate, occasionally with 1 longitudinal septa (Fig. 5).

Habitat. The species is encountered on clayey and calcareous soils, in open habitats. Its specimens grows in wet places, on eroded slopes of river valleys as well as in excavations of gravel pits and brickyards, and on dumps. Associated lichens are few, although some Collema species for example Collema crispum, C. limosum have been recorded; somtimes Leptogium byssinum and Verrucaria bryoctona are also present.

Distribution in Poland. In the whole territory of Poland, it is a rare, ephemeral species appearing at sites dispersed both in the lowlands and mountains. In the Kujawy and neighbouring areas adjoining the lower Vistula the species is recorded at 25 sites but in nothern part of Poland it is alredy recorded only from Mazurian Lakeland and the the Baltic costal zone. In more central and southern parts of the country it is dispersed in the Świętokrzyskie Mts, and the neighbouring uplands as well in the Sudeten Mts and the Carpathians Mts (see Fałtynowicz 2003).

General distribution Thelidium zwackhii occurs in Europe in (south boreo-)temperate zones (Wirt 1995) from Spain, France and British Islands (Purvis et al. 1994) in the west through central Europe (Wirth 1995a) tu Ukraine (Bielczyk \& Kiszka 2000). In the north it have been reported encountered from Fenoscandia (Santeson et al. 2004) and Lithuania (Motiejūnaite 2002), in the south from Italy (Nimis \& Martellos 2004). Outside Europe it has been recorded from North America (Harris \& Lendemer 2005) and Australia (Filson 1996).

Specimens examined. Poland. The Kujawy District and some neighbouring areas: CC-24 - between Ślesin an Trzeciewnica 20 October 1996; CC-28 - Rzęczkowo 6 October 1991; CC-32 - Karmelita near Kcynia 12 October 1995; CC-56 - Piechcin by a limestone quary 28 October 1994; Białe Błota near Piechcin and Wapienno near 

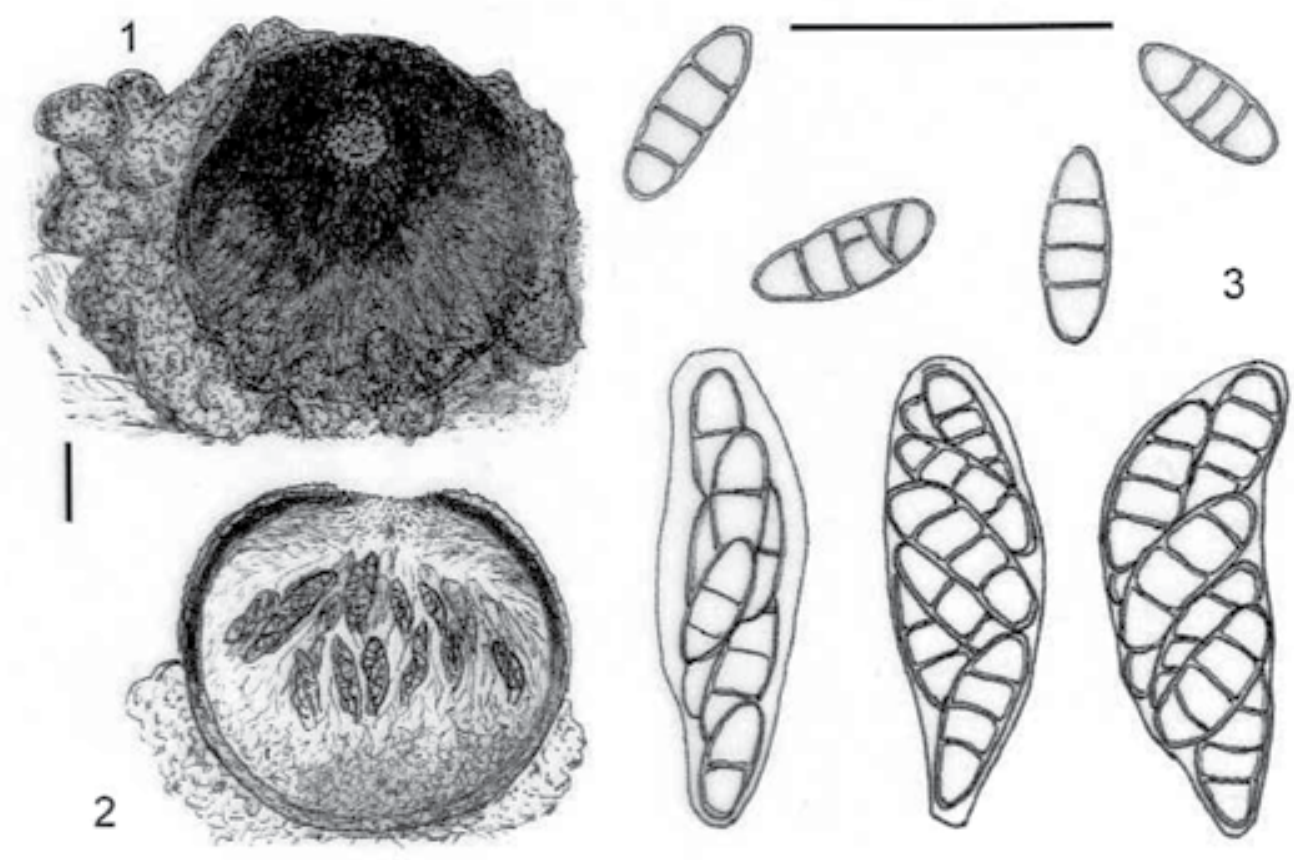

Figure 5. Thelidium zwackhii (original; locality: Wapienno 28.09.1994), 1 - mature perithecium; 2 - section of mature perithecium, 3 - asci and ascospores. Scales: $1 \& 2=50 \mu \mathrm{m} ; 3=50 \mu \mathrm{m}$

Piechcin 28 September 1994; CC-66 - Mikołajkowo near Radłowo 13 June 1998; CC-98 - Mielnica Duża 23 October 1996; CC-03 Koronowo 14 August 1999; CC-08 Kiełp near Chełmno 15 April 2000; BC-17 - Łubianka near Toruń 9 July 1997; DC 51 - Stawki by Aleksandrów Kujawski; DC-52 - between Nieszawa and Przypust Dolny 24 July 1995; DC-82 - Rzadka Wola near Brześć Kujawski 1 June 1995; Parcele by Brześć Kujawski 22 June 1995; DC-94 - Baruchowo near Kowal 16 June 1995; CD-09 Pogorzele near Sompolno 22 August 1998; Błonawy near Lubstów 22 August 1998; DD-00 - Brzezie-Mostki 1 October 1996; DD-22 - Kłodawa 1 October 1996; DB-35 - Dzierzgoń 23 September 1997; DB-86 - betwee Nawra and Bratian near Nw. Miasto Lubawskie 24 September 1997; CB-27 - Chwarzno near Stara Kiszewa 24 July 1997; CB-39 - Sucumin near Starogard Gd. 31 August 1996; CB-52 - Polnica near Chojnice 18 October 1999. All specimens examined was collected by M. Ceynowa-Giełdon and housed at herb. TRN.

\section{Acknowledgements}

The authors are grateful to the anonymous reviewer for critical comments on the manuscript.

\section{References}

Adamska E., 2010, Biota of lichens on the Zadroże Dune and its immediate surroundings, Ecological Questions 12: $51-28$.

Adamska E., 2012, Protected and threatened lichens in the city of Torun, [in:] L. Lipnicki (ed.) Lichens Protection - Protected Lichen Species, Sonar Literacki, Gorzów Wielkopolski: 313-323.

Alstrup V. \& Olech M., 1992, Checklist of the lichens of the Tatra National Park, Poland, Zeszyty Naukowe Uniwersytetu Jagiellońskiego, Prace botaniczne 24: 185206.

Barreno E. \& Renobales G., 1985, Aportaciones a la flora liquénica del País Vasco (España), Rocas calcáreas, I, Anales del Jardín Botánico de Madrid 42(1): 61-80. 
Bielczyk U., 2003, The lichens and alliend fungi of the Polish Western Carpathians, [in:] U. Bielczyk (ed.) The lichens and allied fungi of the Polish Carpathians - an anotated checklist, W. Szafer Istitute of Botany, Polish Academy of Sciences, Kraków: 25-232.

Bielczyk U. \& Kiszka J., 2000, Contribution to the lichen flora of Western Ukraine. Fragmenta Floristica et Geobotanica Polonica 45(1-2): 493-500.

Bielczyk U., Lackovičová A., Farkas E. E., Lőkös L., Liška J., Breuss O. \& Kondratyuk S. Y, 2004, Checklist of lichens of the Western Carpathians, W. Szafer Istitute of Botany, Polish Academy of Sciences, Kraków.

Ceynowa-Giełdon M., 2001, Kalcyfilne porosty naziemne na Kujawach [Calciphilous terricolous lichens in $\mathrm{Ku}$ jawy], Wydawnictwo Uniwersytetu Mikołaja Kopernika, Torun.

Ceynowa-Giełdon M., 2007, Thelidium rimosulum (Verrucariaceae, lichenized Ascomycota), a new lichen species from Poland, The Lichenologist 39(3): 217-220.

Cieśliński S., Czyżewska K. \& Fabiszewski J., 2006, Red list of the lichens in Poland, [in:] Z. Mirek, K. Zarzycki, W. Wojewoda, Z. Szeląg (eds.), Red list of plants and fungi in Poland, W. Szafer Institute of Botany, Polish Academy of Sciences, Kraków: 73-89.

Cieśliński S. \& Łubek A., 2003, Czerwona lista porostów zagrożonych w Górach Świętokrzyskich [Red list of threatened lichens in the Świetokrzyskie Mts], Monographiae Botanicae 91: 143-158 (in Polish with English abstract).

Czarnota P., 2003, Czerwona lista porostów zagrożonych w Gorcach [Red list of threatened lichen in the Gorce Mts], Monographiae Botanicae 91: 159-176 (in Polish with English abstract).

Eitner E., 1901, II Nachtrag zur Schlesischen Fflechtenflora, Jahrb. Schles. Ges. vaterl. Kultur 78: 5-27.

Fałtynowicz W., 2003, The lichens, lichenicolous and allied fungi of Poland - an annotated Checklist, W. Szafer Institute of Botany, Polish Academy of Sciences, Kraków.

Filson R. B., 1996, Checklist of australian lichen and allied fungi, Flora of Australia Supplementary Series Number 7, Australian Biological Resources Study, Superseded by No. 19 .

Harris R. C. \& Lendemer J.C., 2005, Contributions to the Lichen Flora of Pennsylvania: A. Checklist of Lichens Collected During the First Howard Crum Bryological Workshop, Delaware Water Gap National Recreation Area, Opuscula Philolichenum 2: 1-10.

Kiszka J., 1997, Nowe dla Pienin gatunki porostów Cz. I [New lichens species in the Pieniny Mts Part I], Fragmenta Floristica et Geobotanica Polonica Ser. Polonica 4: 325-328.

Kościelniak R., 1998, Porosty epilityczne Bieszczadów Niskich [Epilithic lichens of the Bieszczady Niskie Mts], [in:] K. Czyżewska (ed.), Różnorodność biologiczna porostów [Lichen biological diversity], Wydawnictwo Uniwersytetu Łódzkiego, Łódź: 122-133 (in Polish with English abstract).

Kościelniak R., 2004, Porosty (Lichenes) Bieszczadów Niskich [The lichens of the Bieszczady Niskie Mts], Instytut Botaniki im. W. Szafera, Polska Akademia Nauk, Kraków.

Kościelniak R. \& Kiszka J., 2003, The lichens and allied fungi of the Polish Eastern Carpathian, [in:] U. Bielczyk (ed.), The lichens and allied fungi of the Polish Carpathians. An annotated checklist, W. Szafer Institute of Botany, Polish Academy of Sciences, Kraków: 233294.

Kozik R., 1977, Porosty (Lichenes) Pogórza Rożnowsko-Cieżkowickiego [The lichens of the Rożnów-Cieżkowice foothills (Polish Western Carpathians)], Fragmenta Floristica et Geobotanica Polonica 23(2): 215-252.

Kossowska M., 1999, Lichens growing on calcareous rocks in the Polish part of the Sudety Mountains, ABS monogr 3pdf (Obiekt application/pdf) Uniw. Wr., Wrocław.

McCarthy P. M., 2006, Checklist of the lichens of Australia and its island territories, Australian Biological Resources Study, Canberra, Version 6 April 2006, [http: // www.anbg.gov.au/abrs/lichenlist/introduction.html], Bd. 119. Nr 8. C. A. Retzels Forlag, København.

Motiejūnaitè J., 2002, Diversity of Lichens and Lichenicolous Fungi in the Transboundary Region of Marijampolè District (Southern Lithuania), Botanica Lithuanica 8(3): 277-294.

Nimis P. L. \& Martellos S., 2004, Keys to the lichens of Italy, I Terricolous species, Edizionani Goliardiche, Trieste.

Nowak J., 1961, Porosty Wyżyny (Jury) Krakowsko-Częstochowskiej [The lichens of the Krakowsko-Częstochowska upland], Monographiae Botanicae 11.2: 1-126.

Nowak J. \& Tobolewski Z., 1975, Porosty polskie [The lichen flora of Poland], Państwowe Wydawnictwo Naukowe Warszawa - Kraków.

Nowak J., 1965, Porosty Beskidu Małego [The lichens of the Beskid Mały (Polish Western Carpathians)], Fragmenta Floristica et Geobotanica Polonica 11(3): 421462.

Orange A., 1991, Notes on some terricolous species of Verrucaria, Lichenologist 23(1): 3-10.

Purvis O. W. Coppins B. J., Hawksworth D. L., James P. W. \& Moore D. M., 1994, The lichen flora of Great Britain and Ireland, Natural History Museum Publications in association with The British Lichen Society, London.

Santesson R., Moberg R., Nordin A., Tønsberg T. \&. Vitikainen O., 2004, Lichen - forming and lichenicolous fungi of Fennoscandia, Museum of Evolution, Uppsala University, Majornas Copy Print AB, Götenborg, Uppsala. 
Søchting U. \& Alstrup V., 2002, Danish lichen checklist, Botanical Institute, University of Copenhagen, Copenhagen.

Swinscow T. D. V., 1971, Pyrenocarpous lichens: 15. Key to Polyblastia Massal. in the British Isles, Lichenologist 5: 92-113.

Śliwa L. \& Krzewicka B., 2012, New records of Pyrenocarpous crustose lichens in the Polish Tatra Mts and surroundings, Polish Botanical Journal 57(2): 46-471.

Tobolewski Z., 1958, Porosty Pienin [The lichen flora in the Pieniny], Prace Komisji Biologicznej PTPN 17(5): $1-124$.

Wirth V., 1995a, Flechtenflora: Bestimmung und ökologische Kennzeichnung der Flechten Südwestdeutschlands und angrenzender Gebiete, Verlag Eugen Ulmer, Stuttgart.

Wirth. V., 1995b, Die Flechten Baden-Württembergs Teil 2, E.U. Verlag Eugen Ulmer, Stuttgart (Hohenheim).
Wong P. Y. \& Brodo J. M., 1990, Significant records from the lichen flora of southern Ontario, Canada, The Bryologist 93(3): 357-367.

Zschacke H., 1934, Epigloeaceae, Verrucariaceae und Dermatocarpaceae, [in:] A. Zahlbruckner (ed.) Rabenhorst's Kryptogamen-Flora von Deutschland, Österreich und der Schweiz, 2, Aufl. 9(1/1): 44-695, Akademische Verlagsanstalt, Leipzig.

Zając A., 1978, Atlas of distribution of vascular plants in Poland (ATPOL), Taxon 27(5/6): 481-484.

Zalewska A., 2012, Ecology of lichens of the Puszcza Borecka Forest (NE Poland), W. Szafer Institute of Botany Polish Academy of Sciences, Kraków. 